\title{
KEBIJAKAN PENGATURAN PAJAK HOTEL DAN PAJAK RESTORAN SEBAGAI DAMPAK WABAH COVID-19 DALAM RANGKA PEMENUHAN PENDAPATAN ASLI DAERAH
}

\author{
Amelia Ayu Paramitha; Fakultas Hukum Universitas Brawijaya; E-mail: \\ ameliaparamitha27@gmail.com
}

\begin{abstract}
Abstrak
Covid-19 berimplikasi pada segi sosial, pertumbuhan ekonomi, penurunan penerimaan negara dan daerah dan pertumbuhan ekonomi yang mengalami kelambatan sehingga pendapatan negara maupun daerah tidak mencapai target yang diinginkan. Pemerintah tidak hanya melakukan tindakan upaya kesehatan dan penanganan wabah ini tetapi juga melakukan upaya ekonomi yang tetap harus berjalan dalam kondisi pandemi melalui kebijakan dan langkah besar yang dilakukan. Pemerintah Pusat mengeluarkan Peraturan Pemerintah Pengganti UndangUndang Nomor 1 Tahun 2020 tentang Kebijakan Keuangan Negara dan Stabilitas Sistem Keuangan untuk Penanganan Pandemi Corona Virus Disease 2019 dan masing-masing daerah mengeluarkan beberapa kebijakan-kebijakan terkait dengan pemenuhan pendapatan asli daerah, terlebih lagi bagi Kota Malang yang juga terdampak terkait dengan pengaturan pajak daerah yaitu pajak hotel dan pajak restoran yang memberikan sumbangsih besar terhadap PAD Kota Malang. Tujuan dari penelitian ini melihat apa implikasi terhadap kondisi eksisting penurunan tarif pajak hotel dan restoran di Kota Malang dalam kondisi pandemi saat ini. Penelitian ini menggunakan jenis penelitian yuridis normatif dan dengan jenis pendekatan penelitian pendekatan perundang-undangan, pendekatan kasus, pendekatan konseptual. Hasil penelitian mengenai implikasi kondisi di Kota Malang dan upaya Pemerintah Kota Malang untuk menanggulangi penurunan PAD melalui kebijakan-kebijakan yang diberikan salah satunya memberikan keringanan kepada wajib pajak hotel dan restoran dalam kondisi pandemi dan memberikan kebebasan dalam pembayaran denda pajak bagi pihak hotel dan restoran yang tentunya disesuaikan dengan kondisi dan persyaratan tertentu sehingga PAD Kota Malang dari sector pajak daerah tetap berjalan dan mampu memenuhi target yang telah ditentukan sebagaimana mestinya.
\end{abstract}

Kata Kunci: Kebijakan, Pajak Hotel dan Restoran, Pendapatan Asli Daerah

\begin{abstract}
Covid-19 has had many impacts from various aspects of life and has also caused many casualties and large material losses so that it has implications for the social, economic growth, decline state and regional revenues and slowing economic growth so that state and regional revenues do not reach the desired targets. The government as a whole, both central and local, has taken health measures and handling this outbreak but has also made economic efforts that must continue in this pandemic state through policies and major steps taken. The Central Government issued a Government Regulation in Lieu of Law Number 1 Year 2020 Regarding State Financial Policy and Financial System Stability for Handling the Corona Virus Disease 2019 Pandemic Pandemic and each region issued several policies related to meeting local revenue. Moreover, Malang City is also affected by regulating local taxes, namely hotel tax and restaurant tax, which make a big contribution to Malang's PAD. The purpose of this study is to see what are the implications for the existing conditions of reducing hotel and restaurant tax rates in Malang City in the current pandemic condition. This study uses a juridical normative research type and the statute approach, the case approach, the conceptual approach. The results of research regarding the implications of conditions in Malang City and the efforts of the Malang City Government to overcome the reduction in PAD through policies that are given, one of which is to provide relief to hotel and restaurant taxpayers in pandemic conditions and to provide freedom in paying tax fines for hotels and restaurants, of course adjusted to certain conditions and requirements so that the PAD of Malang City from the regional tax sector continues to run and is able to meet the predetermined targets as it should.
\end{abstract}

Keywords: Policy, Hotel and Restaurant Tax, Local Revenue 


\section{PENDAHULUAN}

\section{Latar Belakang}

Negara Indonesia adalah sebuah Negara Kesatuan, Negara yang juga terdiri akan banyaknya pulau-pulau dan daerah-daerah, sehingga di Indonesia terdapat otonomi daerah yang melahirkan daerah otonom sesuai berdasarkan asas desentralisasi yang dianut. Pengertian dari desentralisasi yaitu desentralisasi merupakan "kebijakan pemerintah pusat kepada pemerintah daerah dengan memberikan kewenangan kepada pamerintah daerah untuk melakukan pengaturan dan mengurus segala hal yang berkaitan dengan pemerintahan daerah di tempatnya serta mengelola keuangan daerahnya masing-masing. ${ }^{1}$

Sesuai dengan pengertian dari asas desentralisasi, maka pemerintah daerah mempunyai kewenangan untuk mengatur daerahnya masing-masing, tujuannya adalah salah satunya untuk mengedepankan sebuah kemandirian dalam daerah untuk dapat berjalan sendiri, mengatur dan bersaing dengan daerah satu dengan lainnya sehingga tercipta suatu kehidupan masyarakat yang baik dan tidak tersentralisasi di pemerintah pusat. Pelaksanaan otonomi daerah ini juga tidak terlepas dari berbagai hal termasuk juga dampak yang dihadapi, antara lain adalah dalam hal pembiayaan yang digunakan untuk menjalankan suatu roda pemerintahan daerah, diperlukannya kemandirian dalam hal keuangan sehingga dalam hal ini pemerintah daerah berdasarkan kewenangan yang dimiliki berhak untuk mengatur serta mengoptimalkan segala potensi daerah yang dimiliki guna adanya pemasukan dalam pendapatan daerah untuk pelaksanaan berjalannya roda pemerintahan daerah.

Untuk mewujudkan apa yang menjadi visi dan misi suatu daerah dan juga melakukan pengembangan baik dari segi fasilitas umum dan pembangunan di berbagai bidang khususnya di daerah maka pembangunan lebih diarahkan ke daerah-daerah, sehingga daerah mempunyai wewenang untuk mengatur urusan rumah tangganya sendiri yang disesuaikan dengan peraturan yang berlaku sehingga daerah-daerah otonom mempunyai kewenangan yang telah tercantum dalam UU No. 23/2014 dan UU No. 33/2004. Dalam melaksanakan urusan pemerintahan tersebut, tiap-tiap daerah otonom/pemerintah daerah memerlukan dana/biaya operasional yang telah diatur dalam tiap-tiap APBD masing-masing daerah. Kebijakan manfaatkan keuangan dilakukan dalam wadah PAD yang dimana sumber utamanya adalah pajak daerah dan retribusi daerah. ${ }^{2}$ Adapun untuk sumber-sumber penerimaan daerah antara lain pajak dan retribusi daerah; hasil-hasil yang diperoleh dari pengelolaan kekayaan daerah yang dipisahkan; serta pendapatan asli daerah yang sah; pendapatan transfer yang meliputi dana perimbangan; dana otonomi khusus; dana keistimewaan; dana desa; pendapatan bagi hasil; dan bantuan keuangan.

PAD memegang peranan penting dalam sebuah jalannya roda pemerintahan dan menjadi tolok ukur dalam pelaksanaan otonomi daerah, sehingga suatu daerah otonom

\footnotetext{
${ }^{1}$ Bratakusumah, Deddy Supriady \& Riady. (2010). Perencanaan Pembangunan Daerah. Jakarta: PT. Gramedia Pustaka Utama, h. 7.

2 Ahmad Fawaidurrohman. (2019). Analisis Kontribusi Pendapatan Asli Daerah terhadap APBD Kabupaten Bangkalan Tahun 2014-2018, E-JRA, Vol. 8, No. 11, h. 87.
} 
dapat berjalanapabila PAD dapat memberikan sumbangan yang cukup untuk pelaksanaan pemerintahan dan berjalannya pembangunan di daerah, maka dapat disimpulkan apabila semakin tinggi kontribusi yang diberikan oleh PAD, maka akan semakin tinggi pula suatu kemampuan daerah untuk membiayai penyelenggaraan pemerintahan dan pembangunan daerahnya.

PAD juga merupakan sumber penerimaan daerah yang mempunyai proporsi yang besar disamping penerimaan pembangunan. PAD merupakan salah satu indikator untuk menilai tingkat kemandirian pemerintah daerah dibidang keuangan. Pemerintah daerah didorong untuk lebih berupaya meningkatkan PAD baik dari sektor pajak, retribusi daerah, dan penerimaan daerah lainnya. Melalui PAD yang semakin meningkat diharapkan pemerintah daerah dapat lebih mandiri dalam pembiayaan pelaksanaan pemerintahan dan pembangunan daerah. Beberapa uraian yang telah disebutkan sangat penting dan masing-masing memberikan sumbangan bagi penghasilan PAD. Oleh karena itu daerah otonom dengan kemandiriannya harus mampu untuk menggali potensi daerah untuk dijadikan sebagai sumber-sumber keuangan serta juga harus mampu mengelola dan menggunakan keuangannya secara mandiri untuk membiayai penyelenggaraan pemerintah daerah.

Upaya menggali sumber-sumber keuangan daerah, terutama dalam meningkatkan pendapatan asli daerah, pemerintah daerah harus berusaha mencari sumber-sumber keuangan yang potensial, dimana sumber keuangan yang potensial bagi daerah adalah mengenai pajak dan retribusi daerah, hasil-hasil yang diperoleh dari pengelolaan kekayaan daerah yang dipisahkan serta pendapatan asli daerah yang sah. Pada umumnya sumber PAD terbesar dari suatu daerah berasal dari pajak dan retribusi daerah. Setiap daerah-daerah otonom memiliki masyarakat dengan berbagai macam aktivitas yang dilakukan, sehingga seiring dengan meningkatnya aktivitas yang terjadi di masyarakat, dan semakin berkembangnya potensi yang dimiliki tiap-tiap daerah otonom, dapat mendorong percepatan dan pertumbuhan ekonomi daerah, serta meningkatnya perekonomian masyarakat. Komponen pendapatan asli daerah dapat memberikan sumbangan yang besar bagi penerimaan daerah.

Seperti yang sudah dijelaskan sebelumnya, bahwa sumber PAD terbesar pada umumnya adalah pajak dan retribusi daerah. Oleh karena itu tiap-tiap daerah otonom harus memaksimalkan pajak dan retribusi daerah. Untuk memaksimalkan pendapatan pajak dan retribusi daerah dapat dilakukan melalui regulasi dan kebijakan tiap-tiap daerah yang telah disesuaikan dengan potensi daerahnya masing-masing. Bentuk geografis Negara Indonesia sebagai Negara kepulauan memiliki pengaruh besar terhadap potensi tiap-tiap daerahnya yang dalam hal ini adalah potensi wisata salahsatunya sebagai sumber PAD. Sebagai dampak dari potensi wisata tersebut, dapat dilihat dari besarnya usaha hotel dan restoran ditiap-tiap daerah otonom di Indonesia, khususnya didaerah pariwisata seperti Bali, Yogyakarta, Malang, dan lain-lain.

Berbicara tentang potensi pariwisata bukan berarti hanya berbicara mengenai keindahan alam saja, banyak faktor-faktor lain yang dapat mempengaruhi. Faktor-faktor tersebut dapat berasal dari dalam dan dapat juga dari luar, seperti kondisi yang dialami 
negara Indonesia dan internasioanal yaitu terkait dengan wabah penyakit yang sudah mendunia dan membawa dampak yang sangat besar bagi seluruh negara termasuk Indonesia, yaitu wabah penyakit Covid-19.

Sejak awal tahun 2020 telah muncul penyakit pandemik baru yang disebut dengan Covid-19. Kemunculan wabah penyakit ini sangat berdampak luas, tidak hanya di negara-negara luar termasuk Indonesia yang sudah mulai terjangkiti oleh wabah virus ini, dengan menyebarnya dan berbahayanya virus ini menyebabkan pemerintah dituntut untuk ekstra bekerja cepat dalam menanggulangi hal tersebut, dan tentunya kebijakankebijakan yang diambil pemerintah pasti akan membawa dampak tertentu di masyakat dan memperngaruhi beberapa sector PAD yang mengakibatkan penurunan, salah satunya adalah pada industri pariwisata. Karena penyakit wabah Covid 19 ini menyebar dengan cepat yakni melalui tetesan kecil (droplet) yang keluar/tersembur melalui hidung atau mulut ketika mereka yang terinfeksi virus bersin atau batuk. ${ }^{3}$ Beberapa Negara telah melakukan berbagai upaya terkait hal ini seperti melakukan lockdown dan social distancing. Lockdown adalah keadaan dimana pemerintah mengunci seluruh akses masuk maupun keluar dari suatu daerah maupun Negara. Sedangkan social distancing adalah keadaan dimana kita dihimbau untuk menjauhi segala bentuk perkumpulan, menjaga jarak dengan manusia, dan menghindari berbagai pertemuan yang melibatkan banyak orang. ${ }^{4}$ Di Indonesia, dampak wabah penyakit corona dalam bidang industri pariwisata sangat terasa hal ini dapat dilihat dari banyaknya tempat wisata yang ditutup sementara dan berkurangnya kunjungan wisatawan baik dalam maupun luar negeri. Terhitung sampai tanggal 10 april 2020, Perhimpunan Hotel dan Restoran Indonesia (PHRI) mencatat sudah ada 1.542 hotel yang tutup di 31 provinsi di Indonesia. Tiga provinsi lainnya masih dalam kepengurusan organisasi dengan PHRI ${ }^{5}$. Selain itu, ternyata wabah corona juga mengakibatkan berbagai efek domino yang sangat krusial juga seperti seiring dengan menurunnya pendapatan dari usaha pariwisata maka mau tidak mau pemilik usaha pariwisata juga akan memotong gaji pekerja atau bahkan merumahkan para pekerjanya sehingga para pekerja disektor industri pariwisata mengalami kerugian yang sangat besar. Seiring dengan melemahnya industri pariwisata maka secara tidak langsung akan melemahkan pemerintahan daerahnya juga terutama daerah-daerah yang sangat bergantung pada Industri pariwisata.

Hal ini pun juga terjadi pada Kota Malang sebagai salah satu daerah yang kaya PAD nya juga besar dari sektor pariwisata khususnya dalam pajak hotel dan pajak restauran. Dimana pada bulan April ini telah direncanakan hotel dan resto di Kota Malang banting harga dan akan menurunkan tarif sebesar 10 persen dari harga biasanya. Rencana ini akan direalisasikan setelah Kementerian Keuangan memberlakukan pajak 0 persen untuk

3 Cara Penyebaran Virus Corona versi WHO (Online),
https:// www.cnbcindonesia.com/tech/20200317193707-37-145644/biar-paham-begini-carapenyebaran-virus-corona-versi-who (18 Maret 2020)

${ }_{4}^{4}$ Mengenal Istilah Seputar Corona (online), https://nasional.tempo.co/read/1320573/ada-odppdp-dan-lockdown-mengenal-istilah-seputar-corona (18 Maret 2020)

${ }_{5}$ Efek Virus Corona ke Wisata RI per 13 April 2020 (Online), https://travel.detik.com/travelnews/d-4928546/efek-virus-corona-ke-wisata-ri-per-13-april-2020 (13 April 2020) 
hotel dan restoran di sepuluh kota termasuk Kota Malang (Malang, Yogjakarta, Manado, Mandalika, Labuan Bajo, Bangka Belitung, Batam, Bali, Bintan dan kabupaten yang mengelilingi Danau Toba). Rencana ini sudah digadang-gadang oleh pemerintah pusat untuk menghapus pajak hotel dan pajak restoran untuk 6 bulan ke depan untuk merespon dampak dari wabah Covid-19. Untuk menekan merosotnya kunjungan wisatawan, kesepuluh daerah tersebut tadi diharapkan masing-masing pemerintah daerah menurunkan tarifnya karena sudah dipungut pajak. Mengingat hal ini merujuk pada kebijakan yang harus dilakukan oleh pemerintah daerah Kota Malang, maka penelitian ini akan meneliti mengenai implikasi dari kebijakan tersebut.

Berdasarkan penjelasan latar belakang di atas maka dalam penelitian ini, penulis ingin mengkaji tentang arah kebijakan pengaturan pajak hotel dan restoran saat wabah Covid-19 dalam rangka pemenuhan pendapatan asli daerah. Penelitian ini difokuskan kepada kebijakan-kebijakan yang dapat diambil saat wabah corona untuk meminimalisir kerugian khususnya dibidang pajak hotel dan restoran.

\section{RUMUSAN MASALAH}

Masalah yang menjadi fokus penelitian ini yaitu bagaimana implikasi terhadap kondisi eksisting terkait dengan penurunan tarif pajak hotel dan pajak restoran dalam pemenuhan PAD di Kota Malang.

\section{METODE PENELITIAN}

Jenis penelitian yang digunakan adalah penelitian yuridis normatif dengan menitikberatkan pada penerapan peraturan hukum yang berlaku saat ini. ${ }^{6}$ Dalam penelitian ini menggunakan 3 (tiga) metode pendekatan penelitian. Pertama yaitu pendekatan perundang-undangan (statute approach) yang dilakukan dengan menelaah semua undang-undang dan regulasi yang bersangkutan tentang isu hukum yang sedang ditangani. Kedua yaitu pendekatan kasus (case approach), yaitu dengan melakukan telaah pada kasus-kasus yang berkaitan dengan isu hukum yang dihadapi. Ketiga yaitu pendekatan konseptual (conceptual approach) dengan pendekatan ini penulis menggunakan pandangan-pandangan dan doktrin-doktrin yang berkembang di dalam ilmu hukum sebagai dasar pijakan untuk membangun dan memberikan argumentasi hukum atas isu yang diteliti.

Bahan hukum yang digunakan mencakup bahan hukum primer yang diperoleh melalui inventarisasi peraturan perundang-undangan yaitu UUD NRI Tahun 1945; UU No. 17/ 2003 tentang Keuangan Negara; UU No. 28/2009 tentang Pajak Daerah dan Retribusi Daerah; UU No. 12/2011 tentang Pembentukan Peraturan PerundangUndangan; UU No. 23/2014 tentang Pemerintahan Daerah. Bahan hukum sekunder meliputi literatur-literatur yang terkait dengan permasalahan yang dikaji yang berasal dari buku-buku, pendapat ahli hukum dari segi kepustakaan, dan artikel di internet. Dan

\footnotetext{
6 Johnny Ibrahim. (2006). Teori dan Metodologi Penelitian Hukum Normatif. Malang: Bayumedia Publishing, h. 295.
} 
bahan hukum tersier dari KBBI, kamus hukum, dan berbagai kamus lain yang dibutuhkan.

\section{PEMBAHASAN}

\section{A. Kondisi Kota Malang dalam Masa Kondisi Darurat Pandemi Covid-19}

Penyebaran Corona Virus ini yang terjadi hampir di seluruh dunia termasuk Indonesia mengalami peningkatan dan membawa banyak korban jiwa yang mengalami kematian, selain itu dalam menghambat penyebarannya juga banyak dilakukan langkah dan upaya dalam membatasi interaksi antara manusia dan juga pengurangan akan kegiatan-kegiatan yang seperti biasa dilakukan tetapi terbatas. Beberapa kerugian juga dialamai oleh banyak secktor sehingga berimplikasi pada aspek ekonomi, soaial dan kesejahteraan masyarakat.

Negara Indonesia juga terdampak turut ikut mengalami berbagai kerugian yang juga besar dari berbagai sektor, akan tetapi Pemerintah Pusat maupun Daerah tetap melakukan upaya dan tetap berkoordinasi untuk menanggulangi wabah penyakit ini dan juga upaya pemerintah untuk memberikan perlindungan kepada masyarakat dan juga sector-sektor ekonomi khususnya yang tetap harus berjalan supaya tidak berhenti laju pertumbuhan ekonomi negara.

Pemerintah Pusat mengeluarkan Peraturan Pemerintah Pengganti Undang-Undang No 1/2020 tentang Kebijakan Keuangan Negara Stabilitas Sistem Keuangan untuk Penanganan Pandemi, selain itu bagi pemerintah daerah mengeluarkan suatu peraturan daerah dan beberapa kebijakan-kebijakan lainnya terkait dengan kengan daerah ataupun pendapatan asli daerah dalam upaya untuk peningkatannya pada masa kondisi darurat Covid-19 ini. Seperti yang diketahui mada saat ini pendapatan asli daerah pastilah mengalami penurunan atau tidak sesuai dengan target yang dituju karena adanya kelesuan ekonomi di masyarakat sehingga pemerintah daerah haruslah dapat mengupayakan agar pendapatan daerah ini tidak menurun secara drastis hingga $0 \%$.

Kota Malang yang juga sebagai kota wisata merupakan salah satu kota yang juga mengalami permasalahan mengenai peningkatan pendapatan asli daerah khususnya dari sektor pajak daerah yaitu pajak hotel dan pajak restoran dimana memberikan pemasukan yang besar ke pendapatan asli daerah Kota Malang dari wisatawan luar negeri dan dalam negeri dan juga mahasiswa serta pendatang lainnya yang datang ke Kota Malang, selain itu karena Malang juga kota pelajar, kota wisata maka juga banyak usaha kuliner dan makanan yang tumbuh dan berkembang, maka jika kita melihat daerah di Kota Malang banyak ditemui berbagai macam café, restoran, tempat makan/kuliner yang unik dan menyuguhkan berbagai macam nuansa dan menu khas, hal ini pun cukup mendongkrak pendapatan asli daerah kota malang dari setor pajak daerah yaitu pajak restoran.

Dalam hal upaya penanggulangan Covid-19 ini Pemerintah Kota Malang juga menunjuk beberapa rumah sakit pemerintah maupun swasta untuk dapat menerima dan menangani pasien Covid-19 dan menyediakan rumah tertentu atau tempat isolasi untuk perawatan pasien Covid-19. Per tanggal 15 April 2020, kejahatan di Kota Malang semakin merajalela. Peristiwa penjambretan hingga pencurian dan kejahatan di jalanan lainnya 
banyak menimpa warga Kota Malang. Bahkan, pihak kepolisian sebelumnya juga sudah menyampaikan jika kriminalitas dan kejahatan di jalanan mengalami peningkatan selama satu pekan terakhir.

\section{B. Implikasi Terhadap Kondisi Eksisting Terkait dengan Penurunan Tarif Pajak Hotel dan Pajak Restoran dalam Pemenuhan PAD di Kota Malang}

Pandemi virus corona atau Covid-19 memberikan dampak yang besar terhadap perekonomian global.Ini termasuk pula sektor perpajakan. Seberapa lama pandemi ini berlangsung dan seberapa dalam dampaknya bagi aktivitas sosial-ekonomi akan menentukan masa depan sektor perpajakan di Indonesia.

Berbagai dampak yang dialami telah bermunculan terutama dalam hal ekonomi nasional yang mengalami kelambatan dan tidak memenuhi target yang ditentukan, banyak faktor yang mempengaruhi hal tersebut selain dikarenakan menurunnya daya beli dan daya saing masyarakat khususnya dalam kondisi pandemic ini juga keterbatasan yang tidak dapat dilakukan seperti hal biasanya sehingga membawa dampak baik secara langsung maupun tidak langsung terhadap penurunan penerimaan negara dan daerah juga peningkatan pembelanjaan negara dan daerah serta biaya yang tak terduga yang harus dikeluarkan demi kesejahteraan masyarakat dalam kondisi pandemi sekarang ini. Oleh karena itu berbagai upaya dalam penanggulangan baik untuk penyelamatan di bidang kesehatan khususnya yang terdampak langsung akan covid-19 ini juga penanggulangan terhadap perekonomian nasional demi kesejahteraan masyarakat serta berfokus pada pemulihan ekonomi dimana banyak sekali dunia usaha dan masyarakat yang terdampak. Akibat dari hal tersebut pemerintah juga harus menggelontorkan dana cadangan yang digunakan untuk menanggulanginya dan pastinya akan juga berdampak pada sistem keuangan yang mengalami penurunan sehingga perlu segera diambil kebijakan-kebijakan dan juga langkah yang sangat besar terkait dengan hal stabilitas sektor keuangan untuk penyelamatan perekonomian dan keuangan yang stabil.

Pemerintah Pusat menentukan langkah dengan PP Pengganti UU No 1/2020 mengenai Kebijakan Keuangan Negara dan juga mengenai Stabilitas Sistem Keuangan Untuk Penanganan Pandemi. Sedangkan Pemerintah Daerah mengeluarkan berbagai kebijakannya masing-masing sesuai dengan kebutuhan daerahnya masing-masing yang tetap disesuaikan dengan peraturan perundang-undangan diatasnya.

Penurunan penerimaan daerah pada masa pandemi Covid-19 ini pastilah sangat banyak dirasakan oleh berbagai daerah, terlebih juga Kota Malang, pasalnya banyak sektor ekonomi menurun kinerjanya dan bahkan banyak yang tutup dan gulung tikar karena kondisi pandemi ini. Oleh karena itu Pemerintah Kota Malang mengupayakan bagaimana pendapatan atau penerimaan daerah khususnya dari pajak daerah tersebut tidak menurun secara drastis meskipun dalam tahun ini tentunya tidak akan sesuai dengan target yang ditentukan.

Kota Malang sebagai Kota Bunga, Kota Pendidikan dan juga wisata tentunya sangat terdampak akan pandemi ini, apalagi penerimaan pajak daerah yang didapat dari sektor pajak hotel dan pajak restoran pasti tidak akan sesuai dengan target, diharapkan pula 
penerimaan dari kedua sektor tersebut ataupun yang lain juga tidak akan turun secara drastis tetapi dapat dilakukan upaya dan kebijakan serta solusi-solusi dalam pemenuhan pendapatan dan penerimaan daerah khususnya dalam sektor pajak hotel dan pajak restoran. Pemerintah Kota Malang sendiri juga telah mengeluarkan berbagai kebijakan, seperti :

1. Peraturan Walikota Malang Nomor 19 Tahun 2020 Tentang Pedoman Penerapan Masyarakat Produktif dan Aman Corona Virus Disease 2019

2. Surat Edaran Wali Kota Malang Nomor 15 Tahun 2020 Tentang Kesiapsiagaan Dunia Usaha Dalam Menghadapi Corona Virus Disease (Covid-19)

3. Kebijakan berupa Pembebasan atau Penurunan Tarif Pajak Hotel dan Pajak Restoran.

Sejak masa pandemi, bisnis kuliner di Kota Malang mengalami penurunan. Omset penjualan turun secara drastis hal ini dikarenakan pelanggan yang berasal dari luar kota tidak bisa masuk Malang dikarenakan adanya aturan pembatasan masuk ke Kota Malang untuk menghindari tersebarnya wabah penyakit Covid-19, sehingga banyak sekali wisatawan yang menunda kunjungan ke Malang dan perjalanan travel juga terhambat yang berimplikasi pada hasil yang diperoleh dalam pemungutan pajak daerah. Sedangkan warga Malang memilih berhemat karena pendapatan berkurang.kebijakan pemerintah menutup tempat wisata selama pandemi tak hanya memukul industri pariwisata. Namun, bisnis kuliner juga terpengaruh. Pendapatan menjadi menurun, sebagian menutup usaha, pengurangan pegawai dan pemecatan pegawai.Saat penerapan Pembatasan Sosial Berskala Besar (PSBB) juga membuat semua orang memutar otak untuk melakukan berbagai inovasi dan untuk bertahan hidup.

Dalam hal upaya Pemerintah untuk menanggulangi wabah penyakit Covid-19 ini tak lepas juga dari upaya Pemerintah Kota Malang melakukan penerapan Pembatasan Sosial Berskala Besar (PSBB) setelah dikeluarkannya Keputusan Menteri Kesehatan mengenai protokol kesehatan bagi masyarakat dalam pengendalian covid yang tercantum dalam Nomor HK.01.07/MENKES/382/2020 di Wilayah Kota Malang, Kabupaten Malang dan Kota Batu Jawa Timur. PSBB tidak hanya dipandang sebagai sebuah upaya pemerintah dalam usaha untuk mengurangi atau memutus mata rantai dari penyebaran wabah penyakit Covid-19 ini akan tetapi banyak hal yang perlu dipersiapkan terutama dampak sosilogis dan dampak ekonomi yang terjadi sepanjang PSBB diberlakukan. Hal ini tentunya juga berpengaruh terhadap pajak daerah yang salah satunya adalah pajak hotel dan pajak restoran, dimana Kota Malang sebagai kota wisata yang pastinya pemasukan dari pajak hotel dan pajak restoran sangatlah besar, akan tetapi pada masa PSBB pendapatan tersebut pasti menurun dan tidak akan mencapai target, sehingga upaya Pemerintah Kota Malang menanggulangi hal tersebut adalah memberikan keringanan dalam pembayaran pajak daerah, untuk pajak restoran dan pajak daerah adalah $50 \%$ dan bagi tempat usaha yang tutup sementara untuk jangka waktu tertentu selama masa PSBB dan pandemi ini adalah $0 \%$ dengan membuat surat pernyataan yang nantinya akan ditindak lanjuti oleh Bapenda Kota Malang.

Dalam perkembangan pada saat masa pandemi ini, sebagian orang dapat mampu memahami kondisi danada juga yang tidak, tidak mungkin juga dalam kurun waktu 
yang lama pada masa pandemi ini, kegiatan tidak berlangsung, maka pemerintah mengambil kebijakan segala kegiatan dapat dilaksanakan tetapi tentunya tetap dengan menerapkan protokol kesehatan dan saling menjaga satu sama lain. Kini, saat masa transisi menuju kenormalan baru (new normal) Pemerintah Kota Malang mengijinkan untuk dibukanya restoran, hotel dan beberapa tempat wisata dengan tetap melakukan dan menerapkan protokol kesehatan dan membatasi jumlah pengunjung atau orang dalam suatu tempat selain itu juga wajib untuk menyediakan tempat cuci tangan, menjaga jarak tempat duduk dan mewajibkan pengunjung mengenakan masker dan juga cek suhu tubuh guna mencegah penularan dan penyebaran COVID-19.

Dalam hal mulai beroperasinya dan dibukanya hotel serta restoran serta beberapa kegiatan perekonomian lainnya di Kota Malang yang tentunya disesuaikan dengan protokol kesehatan dan dengan jadwal tertentu bagi beberapa tempat dan usaha lainnya maka sesuai Keputusan Menteri Keuangan terhadap kebijakan fiskal dengan membebaskan pajak restoran dan hotel selama enam bulan. Khusus untuk 10 daerah wisata termasuk Malang.Tujuannya adalah untuk menggenjot pendapatan dari sektor pariwisata. Sejak diberlakukannya kelaziman baru (new normal) hotel ataupun restoran yang masih beroperasi akan tetap dikenai pajak. Namun demikian wajib pajak tidak serta merta harus membayar seluruh dari ketentuan pembayaran pajak melainkan dikenakan maksimal 50\% saja sesuai dengan aturan, dengan catatan pengusaha hotel melalui asosiasinya masing-masing mendaftarkan pengajuan keringanan pajak yang nantinya akan ditindaklanjuti oleh Bapenda Kota Malang. Disisi lain, bagi usaha-usaha yang tidak beroperasional maka Wajib Pajak tetap dibebaskan. Untuk pajak restoran maka wajib pajak dapat melaporkan kepada Bapenda apakah restora tersebut tetap beropersi atau tidak. Jika beroperasi maka wajib pajak tersebut tetap melakukan pembayaran pajak yang dikenakan hanya $50 \%$ saja, dan apabila restoran tersebut tidak beroperasi maka dapat mengajukan surat pernyataan tutup sementara selama berapa lama jangka waktunya yang nantinya wajib pajak dibebaskan untuk tidak membayar pajak restoran. Selain itu usaha yang dilakukan oleh Badan Pendapatan Daerah (Bapenda Kota Malang) juga melakukan upaya penjemputan bola dan juga memberikan edukasi dengan turun lapang yaitu mengunjungi sejumlah unit usaha cafe dan restoran yang buka di tengah pandemi. Petugas pajak ini juga memberikan stimulus dan semangat bagi Wajib Pajak (WP) agar dapat bertahan di tengah pandemic, selain dengan silaturahmi, kemudian juga dilakukan dengan mengedepankan edukasi perpajakan kepada para WP. Hal ini merupakan bentuk apresiasi dan dukungan kepada para pengelola usaha yang bangkit kembali dari pandemi Covid-19.

Pembebasan pajak sudah diberikan Pemerintah Kota Malang untuk pelaku usaha yang tutup total.Pelaku usaha yang mulai beroperasi juga sudah diberikan insentif berupa diskon pajak daerah sebesar 50\% ditambah relaksasi pemutihan atau tidak memungut denda jika pelaku usaha terlambat membayar pajak daerah. Selama masa pandemi, Pemerintah Kota Malang memberikan pemutihan denda untuk pajak parkir, pajak hiburan, pajak reklame, BPHTB, pajak daerah hotel dan daerah restoran, pajak air tanah, dan PBB-P2. 


\section{PENUTUP}

Kondisi masa pandemi wabah penyakit Covid-19 ini membawa banyak dampak dari berbagai segi kehidupan baik itu segi sosial, pertumbuhan ekonomi dan hampir dari segi pendapatan negara maupun daerah tidak mencapai target yang diinginkan. Pemerintah secara keseluruhan baik pusat dan daerah telah melakukan tindakan upaya kesehatan dan penanganan wabah ini tetapi juga melakukan upaya ekonomi yang tetap harus berjalan dalam kondisi pandemi ini. Implikasi terhadap kondisi eksisting terkait dengan penurunan tarif pajak hotel dan restoran adalah adanya penurunan pendapatan dari sector pajak daerah khususnya pajak hotel dan restoran, dimana kedua sector pajak daerah ini memberikan kontribusi yang besar dalam pendapatan asli daerah Kota Malang, sehingga dilakukan upaya oleh Pemerintah Kota Malang untuk menanggulangi hal tersebut dan juga untuk memberikan keringanan kepada wajib pajak hotel dan restoran dalam kondisi pandemic saat ini melalui kebijakan-kebijakan yang dikeluarkan yaitu dengan memberikan kemudahan dalam pembayaran dan penarikan pajak daerah dengan memberikan keringanan sebesar $50 \%$ dalam pembayaran pajak yang bagi pihak hotel dan restoran yang beroperasi pada saat era new normal dan juga tidak memungut denda dalam keterlambatan pembayaran pajak maupun pelaporannya. Dan juga untuk wajib pajak pihak hotel dan restoran yang tidak beroperasi maka tidak dikenakan pembayaran pajak sebesar $0 \%$ dengan mengikuti beberapa persyaratan dan aturan yang sudah ditentukan. Sehingga hal ini diharapkan dapat meringankan wajib pajak dari pajak hotel dan pajak restoran dan tentunya juga diharapkan tetap adanya pembayaran pajak daerah tersebut dengan beberapa kebijakan keringanan pembayaran, sehingga pendapatan asli daerah Kota Malang dari sektor pajak hotel dan pajak restoran tetap berjalan dan mampu memenuhi target yang telah ditentukan sebagaimana mestinya.

\section{DAFTAR PUSTAKA}

\section{Buku}

Bratakusumah, Deddy Supriady \& Riady. (2010). Perencanaan Pembangunan Daerah. Jakarta: PT. Gramedia Pustaka Utama.

Budi winarno. (2008). Kebijakan Publik: Teori dan Proses. Medpress: Yogyakarta.

Ilyas, Wirawan B dan Burton Richard. (2004). Hukum Pajak. Edisi Revisi. Jakarta: Salemba

Empat.

Ismail Nawawi. (2009). Public Policy. Surabaya: ITS Press.

Ismanthono, Henricus. (2003). Pendapatan Asli Daerah. Malang: FE Unibraw.

Handoko, T. Hani. (2013). Kontribusi. Yogyakarta: BPFE Yogyakarta.

Halim, Abdul. (2004). Akuntansi Keuangan Daerah. Jakarta: Penerbit Salemba Empat

Johnny Ibrahim. (2006). Teori dan Metodologi Penelitian Hukum Normatif. Malang:

Bayumedia Publishing.

Leo agustino. (2008). Dasar-Dasar Kebijakan Publik. Bandung: Alfabeta.

Moh Nazir. (2005). Metode Penelitian. Jakarta: Ghalia Indonesia, 
Monteiro, Josef M. (2015). Pendidikan Kewarganegaraan: Perjuangan Membentuk Karakter Bangsa. Yogyakarta: Deepublisher.

Riant Nugroho Dwidjowijoto. (2006). Kebijakan Publik untuk Negara-Negara Berkembang. Jakarta: Elex Media Komputindo.

Riant nugroho. (2014). Public Policy. Elex Media Komputindo: Jakarta.

Ronny Hanitijo Soemitro. (1988). Metodologi Penelitian Hukum dan Jurimetri, Jakarta: Ghalia Indonesia.

Sholichin Abdul, Wahab S. (2005). Analisis Kebijaksanaan dari Formulasi Ke Implementasi Kebijaksanaan Negara. Jakarta: Bumi Aksara.

Solichin Abdul Wahab. (2014). Analisis Kebijakan. Jakarta: Bumi Aksara.

Thomas R Dye. (2000). Understanding Public Policy. New Jersey: Hamilton Printing Company.

\section{Jurnal}

Ahmad Fawaidurrohman. (2019). Analisis Kontribusi Pendapatan Asli Daerah Terhadap APBD Kabupaten Bangkalan Tahun 2014-2018, E-JRA, Vol. 8, No. 11.

Hamida El Laila Eka Nur Jannah. (2016). Kontribusi Pajak Daerah Terhadap Pendapatan Asli Daerah, Jurnal Perpajakan (JEJAK), Vol. 10, No.1.

Landiyanto, Erlangga Agustino. (2005). Kinerja Keuangan dan Strategi Pembangunan Kota di Era Otonomi Daerah: Studi Kasus Kota Surabaya. Cures Working Paper, No. 05/01.

\section{Internet:}

Cara Penyebaran Virus Corona versi WHO (Online), https://www.cnbcindonesia.com/tech/20200317193707-37-145644/biar-pahambegini-cara-penyebaran-virus-corona-versi-who (18 Maret 2020)

Mengenal Istilah Seputar Corona (online), https://nasional.tempo.co/read/1320573/adaodp-pdp-dan-lockdown-mengenal-istilah-seputar-corona (18 Maret 2020)

Efek Virus Corona ke Wisata RI per 13 April 2020 (Online), https://travel.detik.com/travel-news/d-4928546/efek-virus-corona-ke-wisata-riper-13-april-2020 (13 april 2020)

Pedoman Pencegahan dan Pengendalian Coronavirus Disease (Covid-19), Direktorat Jendral Pencegahan dan Pengendalian Penyakit Maret 2020 (28 Juli 2020) 